\title{
PENINGKATAN SIFAT FUNGSIONAL BEKASAM MENGGUNAKAN STARTER Lactobacillus acidophilus
}

\author{
Susi Lestari, Rinto ${ }^{\star}$, Siti Balqis Huriyah \\ Program Studi Teknologi Hasil Perikanan, Fakultas Pertanian Universitas Sriwijaya, Jalan Palembang- \\ Prabumulih KM. 32 Indralaya Kabupaten Ogan Ilir Sumatera Selatan 30662, Telp (0711) 580934 \\ Korespondensi: rinto.unsri@gmail.com \\ Diterima: 7 September 2017/ Disetujui: 19 April 2018
}

Cara sitasi: Lestari S, Rinto, Huriyah SB. 2018. Peningkatan sifat fungsional bekasam menggunakan starter lactobacillus acidophilus. Jurnal Pengolahan Hasil Perikanan Indonesia. 21(1): 179-187.

\begin{abstract}
Abstrak
Kualitas bekasam dapat ditingkatkan dengan menggunakan starter bakteri asam laktat (BAL) untuk mengontrol proses fermentasi. Penelitian ini bertujuan untuk mengetahui pengaruh penambahan starter Lactobacillus acidophilus pada proses fermentasi bekasam terhadap karakteristik mikrobiologi, kimia dan sensoris, serta mengkaji sifat fungsional (kandungan lovastatin) dari bekasam ikan seluang (Rasbora argyrotaenia) yang telah diberi perlakuan penambahan starter L. acidophilus. Penelitian ini menggunakan Rancangan Acak Kelompok (RAK) dengan empat taraf perlakuan $\left(0,10^{5}, 10^{7}, 10^{9} \mathrm{CFU} / \mathrm{mL}\right.$ ). Masingmasing perlakuan dilakukan pengulangan sebanyak 3 kali, dengan ulangan sebagai kelompok. Parameter yang diamati meliputi analisis total BAL, kimia, dan sensoris mutu hedonik. Hasil penelitian menunjukan bahwa perbedaan konsentrasi penambahan starter L. acidophilus dalam pembuatan bekasam ikan seluang berpengaruh nyata terhadap kadar protein, $\mathrm{N}$-amino dan lovastatin bekasam. Starter L. acidophillus bisa ditambahkan dalam pembuatan bekasam sampai dengan konsentrasi $10^{7} \mathrm{CFU} / \mathrm{mL}$ untuk meningkatkan kandungan lovastatin.
\end{abstract}

Kata kunci: bekasam, ikan seluang, Lactobacillus acidophillus, lovastatin

\section{Increasing Functionality of Bekasam With Lactobacillus acidophilus as a Starter}

\begin{abstract}
The quality of bekasam can be increased with lactic acid bacteria as a starter to control of fermentation process. The purpose of the research was to investigate the effect of starter Lactobacillus acidophilus addition at bekasam fermentation process to microbiological, chemical, and sensory characteristics. This study also examined the functionaly properties (lovastatin content) in bekasam silver rasbora (Rasbora argyrotaenia) which has been treated with the addition of starter L. acidophilus. This research used the randomized block design with four levels of treatments $(0,105,107,109 \mathrm{CFU} / \mathrm{mL})$. Each treatment was repeated three times, with a replication as a group. The observed parameters were total LAB and chemical characteristics. The result of this research showed the difference of concentration addition of starter L. acidophilus in production of silver rasbora bekasam had a significantly effect to the protein, $\mathrm{N}$-amino, and lovastatin of bekasam. Starter L. acidophilus could be added in bekasam production until $107 \mathrm{CFU} / \mathrm{mL}$ to increase lovastatin content.
\end{abstract}

Keywords: bekasam, Lactobacillus acidophillus, lovastatin, silver rasbora

\section{PENDAHULUAN}

Bekasam merupakan produk fermentasi ikan tradisional yang rasanya asam dan banyak dikenal di berbagai daerah Indonesia, terutama di Sumatera Selatan (Desniar et al. 2011; Rinto et al. 2015a). Proses pembuatan bekasam sampai saat ini masih dilakukan secara tradisional dengan menerapkan fermentasi spontan.
Pertumbuhan mikroorganisme yang berperan selama proses fermentasi, dirangsang dengan penambahan garam dan nasi sebagai sumber karbohidrat dalam kondisi anaerobik, sehingga mikroorganisme yang terdapat pada bekasam beranekaragam sesuai dengan perubahan lingkungan.

Berbagai kajian mikroorganisme khususnya bakteri asam laktat dari 
bekasam telah dilakukan. Bakteri asam laktat dari bekasam dimanfaatkan sebagai starter produk fermentasi (Yanti dan Dali2013), sebagaibakteripenghasil zat antibakteri/bakteriosin (Desniar et al. 2011; Desniar et al. 2016), dan sebagai bakteri probiotik (Marini et al. 2016). Bakteri asam laktat (BAL) telah digunakan secara luas sebagai kultur starter untuk fermentasi daging, susu, dan sayur-sayuran. Peranan BAL adalah untuk memperbaiki cita rasa produk fermentasi, memberikan sifat mengawetkan suatu produk dan dapat meningkatkan nilai daya cerna zat gizi. Hal ini disebabkan karena adanya proses hidrolisis protein menjadi asam amino bebas selama fermentasi (Widowati et al. 2011).

Bakteri asam laktat selama proses fermentasi juga menghasilkan komponen bioaktif yang berfungsi bagi kesehatan, diantaranya yaitu antihipertensi, antibakteri, dan antikolestrol Lactobacillus acidophilus, salah satu BAL yang diisolasi dari bekasam ikan seluang diketahui menghasilkan lovastatin sebagai penghambat sintesis kolestrol (Rinto et al. 2015 ; Wikandari dan Yuanita 2014). Lovastatin tergolong dalam senyawa statin yang dikenal juga dengan nama monakolin Katau mevinolin. Rinto dan Thenawidjaja (2016) menyebutkan bahwa senyawa lovastatin berperan sebagai inhibitor kompetitif bagi enzim HMG-KoA (3-hidroksi-3 metilglutaril Koenzim A) reduktase, yaitu enzim penentu biosintesis kolesterol sehingga dapat membantu menurunkan kadar kolestrol dalam darah. Kasim et al. (2005), menyatakan bahwa lovastatin dapat menurunkan kadar kolesterol darah sebesar 11\%-32\% dan kadar trigliserida sebesar 12\%-19\%.

Penambahan bakteri asam laktat sebagai starter dalam pembuatan bekasam bukan hanya dapat dilakukan untuk memperbaiki kualitas gizi (daya cerna) bekasam namun diharapkan juga dapat meningkatkan nilai fungsional bekasam, oleh karena itu dalam penelitian ini dilakukan penambahan L. acidophilus sebagai starter dalam pembuatan bekasam yang diharapkan berpengaruh positif terhadap karakteristik bekasam dan sifat fungsional bekasam dalam memproduksi lovastatin yang dikenal sebagai antikolestrol. Penelitian ini bertujuan untuk meningkatkan kualitas bekasam secara mikrobiologi, kimiawi, dan sensoris serta meningkatkan kandungan senyawa bioaktif yaitu lovastatin pada bekasam.

\section{BAHAN DAN METODE Bahan dan Alat}

Bahan utama yang digunakan pada penelitian ini adalah ikan seluang (Rasbora argyrotaenia), starter L. acidophilus, garam, nasi, lovastatin (Sigma Aldrich), metanol (Sigma Aldrich), MRS broth (Oxoid), asam triflouro asetat (Merck), formalin (Merck), indikator phenolptalein (Sigma Aldrich). $\mathrm{K}_{2} \mathrm{SO}_{4}$ (Merck), $\mathrm{HgO}$ (Merck), $\mathrm{NaOH}$ (Merck) dan $\mathrm{H}_{3} \mathrm{BO}_{3}$ (Merck), Alat utama yang digunakan dalam penelitian ini yaitu spektrovotometer UV mini-1240 (Shimadzu), sentrifugasi (Shimadzu), tanur (Thermo Scientific), autoklaf (Hyramaya), serta pipet volumetrik (Pipete 100-1000 $\mu \mathrm{L}$ ) dan Smart $0,5-10 \mu \mathrm{L})$.

\section{Metode Penelitian}

Penelitian ini menggunakan metode Rancangan Acak Kelompok (RAK) dengan 4 taraf perlakuan penambahan starter L. acidophilus, masing-masing taraf perlakuan dilakukan pengulangan sebanyak 3 kali, dengan ulangan sebagai kelompok. Taraf perlakuan yang diterapkan adalah sebagai berikut Kontrol, tanpa penambahan starter (A1); Penambahan starter $10^{5} \mathrm{CFU} / \mathrm{ml}$ (A2); Penambahan starter $10^{7} \mathrm{CFU} / \mathrm{ml}$ (A3); dan Penambahan starter $10^{9} \mathrm{CFU} / \mathrm{ml}$ (A4).

\section{Persiapan Kultur L. acidophilus}

Persiapan kultur yang dilakukan pada penelitian ini mengacu pada Rinto et al. (2006), adalah sebagai berikut: Biakan murni L. acidophilus sebanyak 1 ampul diremajakan dalam $5 \mathrm{~mL}$ MRS broth dan diinkubasi pada suhu $37^{\circ} \mathrm{C}$ selama $1 \times 24$ jam, kemudian diambil $1 \mathrm{~mL}$ kultur L. acidophilus dari hasil peremajaan dan ditambahkan dalam $9 \mathrm{~mL}$ MRS broth, diinkubasi pada suhu $37^{\circ} \mathrm{C}$ selama $3 \times 24$ jam. Hasil kultur sebanyak $10 \mathrm{~mL}$ ditambahkan $90 \mathrm{~mL}$ MRS broth dan diinkubasi pada suhu $37^{\circ} \mathrm{C}$ selama 
$3 \times 24$ jam, selanjutnya sebanyak $100 \mathrm{~mL}$ dari kultur sebelumnya ditambahkan $900 \mathrm{~mL}$ MRS broth dan diinkubasi pada suhu $37^{\circ} \mathrm{C}$ selama 3x24 jam untuk mendapatkan starter $10^{9} \mathrm{CFU} / \mathrm{mL}$ dengan volume akhir $1000 \mathrm{~mL}$. Starter L. acidophilus $10^{7} \mathrm{CFU} / \mathrm{mL}$ dibuat dengan pengenceran dari starter $10^{9} \mathrm{CFU} / \mathrm{mL}$. Sedangkan untuk starter $10^{5} \mathrm{CFU} / \mathrm{mL}$ dibuat dengan pengenceran dari starter $10^{7} \mathrm{CFU} / \mathrm{mL}$.

\section{Pembuatan Bekasam Ikan Seluang}

Pembuatan bekasam ikan seluang pada penelitian ini dilakukan dengan metode yang telah dimodifikasi dari Hidayati et al. (2012). Ikan seluang disiangi (dengan membuang sisik, jeroan dan kotoran lainnya). Ikan dicuci bersih dengan air yang mengalir untuk menghilangkan kotoran dan darah yang masih menempel, kemudian ikan ditimbang sebanyak 250 gram dan direndam selama 30 menit dengan kultur bakteri L. acidophilus sesuai perlakuan dengan perbandingan 1:1 dan ditambah es batu. Ikan ditiriskan kemudian dicampur dengan garam $15 \%$ dan nasi $15 \%$ ke dalam toples yang ditutup rapat, selanjutnya dilakukan proses fermentasi pada suhu ruang selama 7 hari.

\section{Prosedur Analisis}

Parameter yang diamati pada penelitian ini yaitu analisis total bakteri asam laktat (Veljovic et al. 2007), analisis kimia yang meliputi kadar air, abu, protein, $\mathrm{N}$-amino dan pH (AOAC 1995), kandungan lovastatin (Rinto et al. 2017) serta sensoris yang meliputi kenampakan, aroma, tekstur, dan rasa dengan menggunakan uji mutu hedonik.

\section{Analisis Data}

Data hasil analisis kimia yang diperoleh dianalisis sidik ragam untuk mengetahui pengaruh perlakuan. Perlakuan yang berpengaruh nyata, maka dilanjutkan uji lanjut beda nyata terkecil (BNT). Data hasil sensoris dihitung menggunakan statistik non parametrik, yaitu dengan metode Kruskal Wallis. Apabila hasil uji Kruskal Wallis menunjukkan bahwa nilai $\mathrm{H}$ lebih besar dari nilai pada tabel $\left(\chi^{2}\right)$, maka dilakukan uji lanjut perbandingan multiple comparison.

\section{HASIL DAN PEMBAHASAN Analisis Total Bakteri Asam Laktat (BAL)}

Proses fermentasi sangat dipengaruhi keberadaan bakteri asam laktat. Jumlah bakteri asam laktat yang ada pada bekasam, sebelum dan setelah proses fermentasi dapat dilihat pada Gambar 1.

Gambar 1 menunjukkan rerata nilai total BAL bekasam setelah fermentasi selama 7 hari cenderung meningkat seiring dengan meningkatnya penambahan konsentrasi starter L. acidophilus yang digunakan. Selsel bakteri asam laktat dapat tumbuh sampai jumlah maksimum di dalam suatu media yang dipengaruhi ketersedian nutrisi pada media tersebut. Hal tersebut sesuai pendapat Hidayat et al. (2013), yang menyatakan bahwa meningkatnya konsentrasi starter diikuti dengan peningkatan jumlah bakteri pada media serta kondisi yang ideal, yang akan diikuti dengan peningkatan aktivitas serta perkembangbiakan bakteri.

Hasil analisis sidik ragam rerata nilai total BAL pada bekasam menghasilkan nilai berbeda tidak nyata pada taraf $5 \%$. Hal tersebut dikarena BAL yang tumbuh dan berkembang pada fermentasi bekasam tidak hanya jenis bakteri L. acidophilus melainkan semua jenis BAL yang secara umumnya berperan dalam proses fermentasi. Candra et al. (2007) berhasil mengisolasi bakteri asam laktat dari golongan Streptococcus dan Lactobacillus serta Staphylococcus dari bekasam.

L. acidophillus yang digunakan sebagai starter merupakan BAL berasal dari bekasam yang diisolasi berdasarkan kemampuannya membentuk lovastatin (Rinto et al. 2015 ${ }^{\mathrm{b}}$ ). Kemampuan antagonis L. acidophillus terhadap bakteri asam laktat maupun bakteri lainnya belum diketahui. Oleh sebab itu masih memungkinkan adanya BAL lain yang juga tumbuh selama proses fermentasi sehingga tidak berpengaruh signifikan terhadap total BAL bekasam.

\section{Komposisi Kimia Kadar Air}

Kadar air merupakan salah satu sifat kimia dari bahan yang menunjukkan banyaknya air yang terkandung di dalam bahan pangan. 


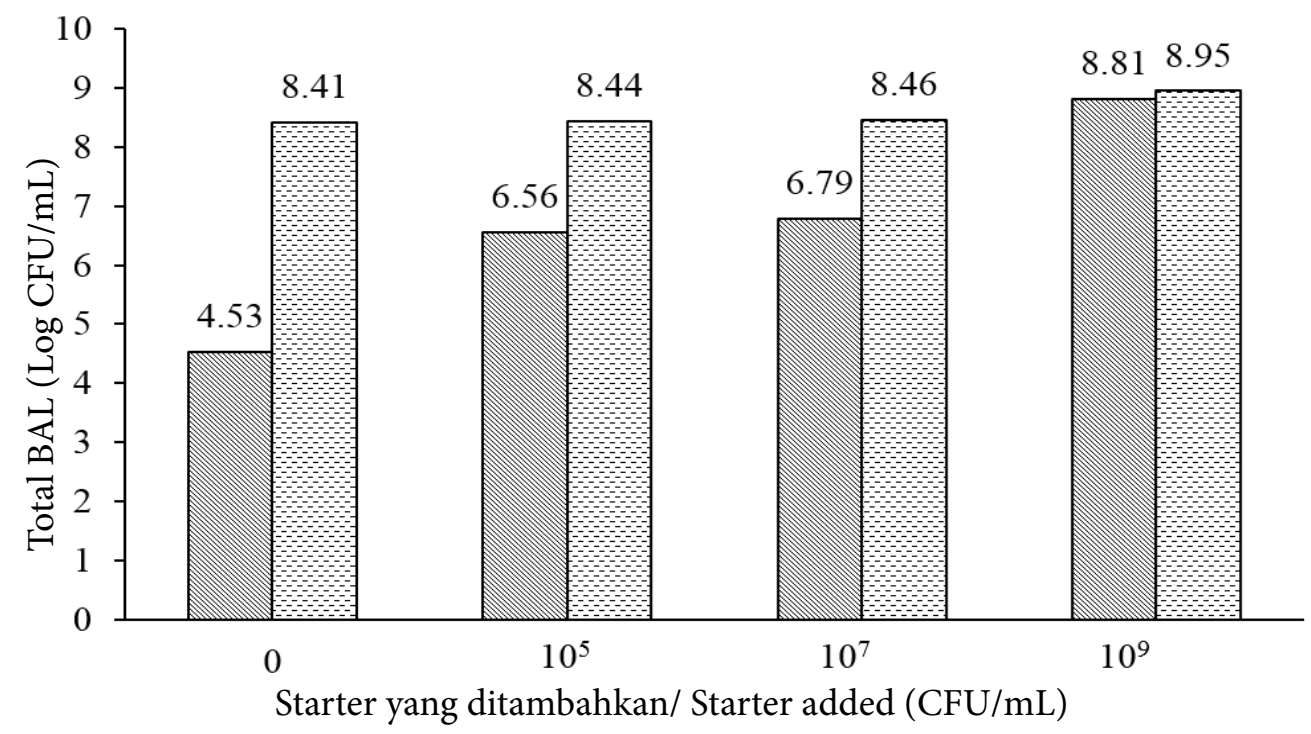

Gambar 1 Nilai total BAL bekasam ikan seluang (ए\zh14) : sebelum fermentasi hari ke- 0 dan ( -3$)$ : setelah fermentasi (hari ke 7))

(Figure 1 Total value of BAL silver rasbora ( $\mathbb{Z}$ ) : before fermentation day 0 and (E-B) : after fermentation (7th day))

Rerata nilai kadar air yang diperoleh pada prosesfermentasiikan seluang dengan berbagai perbedaan konsentrasi penambahan starter L. acidophilus dapat dilihat pada Tabel 1.

Berdasarkan hasil penelitian, nilai kadar air ikan seluang segar adalah 77,92\%. Hasil uji kadar air bekasam pada perlakuan tanpa penambahan starter menunjukan nilai kadar air berkisar antara $67,69 \%-69,18 \%$. Kandungan air bekasam ikan seluang berada pada kisaran penelitian sebelumnya, yaitu Kalista et al. (2012) yang melaporkan bahwa kadar air bekasam ikan lele dumbo berkisaran antara $72,14 \%-74,81 \%$ dan kadar air bekasam ikan patin menurut Widowati et al. (2011), berkisar antara 58,29\% - 67,54\%. Berdasarkan analisis sidik ragam nilai kadar air bekasam berbeda tidak nyata pada taraf $5 \%$. Hal ini menunjukkan bahwa penggunaan starter, tidak berpengaruh signifikan terhadap kadar air bekasam.

\section{Kadar Abu}

Abu adalah residu anorganik dari pembakaran bahan-bahan organik dan komponen-komponennya terdiri darikalsium, natrium, magnesium, dan mangan. Kadar abu dapat menunjukkan total mineral dalam suatu bahan pangan. Pada bahan makanan, sebagian besar (96\%) terdiri dari bahan organik dan air, sisanya terdiri dari unsurunsur mineral. Unsur mineral juga dikenal sebagai zat organik atau kadar abu. Rerata nilai kadar abu yang diperoleh pada proses fermentasi ikan seluang dengan berbagai perbedaan konsentrasi penambahan starter L. acidophilus dapat dilihat pada Tabel 1.

Berdasarkan hasil penelitian, nilai kadar abu ikan seluang segar adalah 2,22\%. Bekasam yang dihasilkan mengandung kadar abu berkisar antara 13,13\%-14,12\%. Bekasam yang mengandung kadar abu terendah yaitu pada perlakuan penambahan starter $10^{7} \mathrm{CFU} / \mathrm{mL}$, sedangkan nilai kadar abu tertinggi yaitu pada perlakuan penambahan starter $10^{9} \mathrm{CFU} / \mathrm{mL}$. Selain berasal dari ikan, mineral-mineral pada produk fermentasi ikan juga berasal dari garam yang ditambahkan yang menyebabkan mineral dalam produk akan semakin meningkat. Soetrisno dan Apriyantono (2005) menyatakan bahwa kadar abu pada bekasam 
Tabel 1 Komposisi kimia bekasam

(Table 1 Chemical composition of bekasam)

\begin{tabular}{ccccccc}
\hline Bekasam & Water $(\%)$ & Ash $(\%)$ & $\begin{array}{c}\text { Protein } \\
(\%)\end{array}$ & $\begin{array}{c}\text { N-Amino } \\
(\%)\end{array}$ & $p H$ & $\begin{array}{c}\text { Lovastatin } \\
(\mathrm{ppm})\end{array}$ \\
\hline A1 & $69.16 \pm 3.24$ & $13.64 \pm 1.13$ & $6.20 \pm 2.44$ & $1.98 \pm 0.20$ & $5.89 \pm 0.15$ & $207.59 \pm 18.20$ \\
A2 & $67.69 \pm 0.51$ & $13.66 \pm 0.34$ & $7.64 \pm 1.84$ & $2.23 \pm 0.20$ & $6.05 \pm 0.22$ & $165.08 \pm 16.25$ \\
A3 & $68.33 \pm 1.13$ & $13.13 \pm 0.22$ & $12.47 \pm 3.14$ & $2.68 \pm 0.20$ & $5.97 \pm 0.13$ & $248.27 \pm 14.53$ \\
A4 & $65.66 \pm 3.34$ & $14.12 \pm 0.50$ & $14.68 \pm 3.27$ & $3.27 \pm 0.20$ & $5.90 \pm 0.17$ & $190.08 \pm 31.95$ \\
\hline
\end{tabular}

Keterangan:

A1 = bekasam tanpa penambahan starter

A2 = bekasam dengan penambahan starter $10^{5} \mathrm{CFU} / \mathrm{mL}$

$\mathrm{A} 3=$ bekasam dengan penambahan starter $10^{7} \mathrm{CFU} / \mathrm{mL}$

$\mathrm{A} 4=$ bekasam dengan penambahan starter $10^{9} \mathrm{CFU} / \mathrm{mL}$

meningkat dibandingkan dengan ikan segar dikarenakan adanya penambahan garam dapur $(\mathrm{NaCl})$. Data rerata nilai kadar abu bekasam ikan seluang yang diperoleh didukung oleh hasil penelitian yang dilakukan Kalista et al. (2012), yang melaporkan bahwa kadar abu bekasam ikan tawes berkisaran antara $11,63 \%-15,27 \%$.

Hasil analisis sidik ragam menunjukkan bahwa perlakuan penambahan starter, memberikan pengaruh yang berbeda tidak nyata pada taraf $5 \%$ terhadap kadar abu bekasam ikan seluang. Hal ini menunjukkan bahwa penggunaan starter $L$. acidophilus, tidak berpengaruh signifikan terhadap kadar abu bekasam. Penambahan jumlah bakteri pada produk fermentasi tidak berpengaruh terhadap kadar mineralnya, yang disebabkan karena bakteri tidak menghasilkan mineral dan hanya memanfaatkan mineral untuk pertumbuhannya dalam jumlah kecil, namun BAL memproduksi beberapa metabolit seperti asam organik seperti asam laktat, asam asetat, hidrogen peroksida, diasetil, dan bakteriosin (Desniar et al. 2012 ${ }^{\mathrm{b}}$.

\section{Kadar Protein}

Protein merupakan sumber asam-asam amino yang mengandung unsur $\mathrm{N}$ yang tidak dimiliki oleh lemak dan karbohidrat. Disamping itu beberapa protein juga mengandung unsur-unsur lain, terutama $\mathrm{P}$, $\mathrm{Fe}, \mathrm{Zi}$ dan $\mathrm{Cu}$. Berdasarkan hasil penelitian, nilai kadar protein ikan seluang segar adalah 9,79\%, setelah difermentasi menjadi bekasam nilai kadar protein berkisar antara 6,20\%$14,68 \%$. Perlakuan yang menghasilkan kadar protein terendah yaitu pada perlakuan tanpa penambahan starter, dan berturut-turut kadar proteinnya meningkat yaitu pada penambahan starter $10^{9}, 10^{7}$, dan $10^{5} \mathrm{CFU} / \mathrm{mL}$. Nilai ratarata kadar protein bekasam ikan seluang dapat dilihat pada Tabel 1.

Hasil analisis sidik ragam menunjukkan bahwa perlakuan penambahan starter, menghasilkan nilai kadar protein bekasam yang berbeda nyata pada taraf $5 \%$. Berdasarkan hasil uji lanjut beda nyata terkecil (BNT) yang dilakukan, menunjukan bahwa kadar protein bekasam ikan seluang pada perlakuan tanpa penambahan starter berbeda tidak nyata dengan perlakuan penambahan starter $10^{5} \mathrm{CFU} / \mathrm{mL}$, tetapi berbeda nyata dengan perlakuan penambahan starter $10^{7}$ dan $10^{9} \mathrm{CFU} / \mathrm{mL}$. Hal ini menunjukan bahwa penambahan starter L. acidophillus lebih dari $10^{7} \mathrm{CFU} / \mathrm{mL}$ mempengaruhi peningkatan protein pada bekasam. Tabel 1 menunjukan bahwa kadar protein selama fermentasi cenderung mengalami peningkatan. Peningkatan kadar protein tersebut diduga karena L. acidophilus merupakan bakteri yang salah satu struktur selnya terdiri dari protein, sehingga penambahan starter $L$. acidophilus berkontribusi dalam peningkatan protein bekasam ikan seluang. Bakteri asam laktat juga menghasilkan bakteriosin yang juga termasuk dalam golongan protein/peptide. Selain itu peningkatan jumlah protein pada 
fermentasi bekasam disebabkan karena adanya enzim dari strain $L$. plantarum, $L$. pentosus, dan Pediococcus pentosaceus pada bekasam Wikandari et al. $\left(2012^{\mathrm{a}}\right)$.

Herawati dan Wibawa (2011) menyatakan bahwa semakin banyak jumlah bakteri asam laktat dalam suatu produk fermentasi maka akan semakin tinggi kadar proteinnya, karena sebagian besar komponen penyusun bakteri asam laktat adalah protein. Soetrisno dan Apriyantono (2005) melaporkan bahwa bekasam ikan teri dengan adanya penambahan kultur menghasilkan kadar protein yang lebih tinggi jika dibandingkan bekasam dengan fermentasi secara spontan.

\section{Kadar N-amino}

Hasil analisis menunjukkan bahwa kadar $\mathrm{N}$-amino bekasam ikan seluang ratarata berkisar antara 1,98\%-3,27\%. Perlakuan yang menghasilkan kadar $\mathrm{N}$-amino terendah yaitu perlakuan tanpa penambahan starter, sedangkan kadar $\mathrm{N}$-amino tertinggi yaitu perlakuan penambahan starter $10^{9}, 10^{7}$, dan $10^{5} \mathrm{CFU} / \mathrm{mL}$. Nilai rata-rata kadar $\mathrm{N}$-amino bekasam ikan seluang dapat dilihat pada Tabel 1.

Hasil analisis sidik ragam menunjukkan bahwa perlakuan penambahan starter, menghasilkan nilai kadar $\mathrm{N}$-amino bekasam yang berbeda nyata pada taraf 5\%. Berdasarkan hasil uji lanjut beda nyata terkecil (BNT) yang dilakukan, menunjukan bahwa kadar $\mathrm{N}$-amino bekasam ikan seluang pada penambahan starter $10^{9} \mathrm{CFU} / \mathrm{mL}$ berbeda nyata dengan semua perlakuan penambahan starter $\left(0,10^{5}\right.$ dan $10^{7} \mathrm{CFU} /$ $\mathrm{mL}$ ). Hal ini menunjukan bahwa peningkatan penambahan starter L. acidophilus lebih dari $10^{7} \mathrm{CFU} / \mathrm{mL}$ telah menyebabkan perbedaan yang nyata terhadap kadar $\mathrm{N}$-amino bekasam.

Tabel 1 menunjukkan bahwa total asam amino bebas berbeda-beda setiap perlakuan. Perlakuan penambahan starter L. acidophilus lebih tinggi dibandingkan tanpa penambahan starter. Hal ini menunjukkan bahwa penambahan L. acidophilus mampu meningkatkan kandungan asam amino bebas selama proses fermentasi. Kadar $\mathrm{N}$-amino yang tinggi dalam proses fermentasi dengan penambahan starter diduga karena adanya enzim proteolitik dari L. acidophilus yang mampu mendegradasi protein ikan menjadi protein-protein terlarut, peptida-peptida, maupun asam-asam amino. Data ini didukung dengan data total bakteri asam laktat yang menunjukkan fermentasi bekasam ikan seluang dengan penambahan starter L. acidophilus menghasilkan jumlah BAL yang lebih tinggi, sehingga degradasi protein ikan menjadi protein-protein terlarut maupun asam-asam amino juga lebih banyak.

Hasil ini juga sesuai dengan penelitian yang dilakukan Wikandari et al. $\left(2012^{\mathrm{a}}\right)$, yang telah membuktikan bahwa bakteri asam laktat mempunyai enzim proteolitik yang dapat mendegradasi protein ikan menjadi peptidapeptida. Protein dapat mengalami degradasi yaitu pemecahan molekul kompleks menjadi molekul-molekul sederhana oleh pengaruh asam, basa atau enzim. Hasil degradasi protein dapat berupa bentuk protease, pepton, polipeptida asam amino, $\mathrm{NH}_{3}$ dan unsur $\mathrm{N}$.

\section{Nilai pH}

Nilai pH menunjukkan derajat keasaman suatu bahan. $\mathrm{pH}$ merupakan konsentrasi ion hidrogen yang terdapat di dalam larutan. Nilai $\mathrm{pH}$ pada pengolahan pangan sangat berperan dalam menentukan daya awet suatu makanan. Keasaman (pH) sangat mempengaruhi mikroorganisme yang dapat tumbuh selain itu juga $\mathrm{pH}$ berpengaruh pada pertumbuhan sel mikroba dan pembentukan produk selama fermentasi. Analisis pH dimaksudkan untuk mengetahui adanya peningkatan senyawasenyawa asam selama fermentasi. Hasil analisis menunjukkan bahwa kadar $\mathrm{pH}$ bekasam ikan seluang rata-rata berkisar antara 5,89-6,05. Perubahan nilai $\mathrm{pH}$ pada bekasam ikan seluang dengan perbedaan perlakuan konsentrasi starter dapat dilihat pada Tabel 1.

Perlakuan tanpa penambahan starter menunjukan bahwa nilai $\mathrm{pH}$ yang lebih rendah (asam) dibandingkan dengan perlakuan lainnya. Hasil analisis sidik ragam menunjukkan bahwa perlakuan penambahan starter, berpengaruh tidak nyata pada taraf $5 \%$ terhadap nilai $\mathrm{pH}$ pada bekasam ikan seluang. Hal tersebut disebabkan karena rerata total BAL yang tumbuh berbeda tidak nyata pada setiap perlakuan, yang 
memungkinkan metabolit asam laktat yang dihasilkan oleh BAL akan mempengaruhi tingkat keasaman bekasam. Penurunan nilai $\mathrm{pH}$ seiring dengan meningkatnya aktivitas bakteri asam laktat. Selain itu menurut Usmam et al. (2012), menyatakan bahwa penurunan $\mathrm{pH}$ dipengaruhi oleh kandungan asam laktat yang dihasilkan oleh BAL.

\section{Sifat Fungsional Bekasam (Kandungan Lovastatin)}

Sifat fungsional bekasam sebagai penurun kolesterol dapat dilihat dari kandungan lovastatin yang terdapat pada bekasam. Hasil analisis kandungan lovastatin menunjukkan bahwa bekasam ikan seluang mengandung lovastatin rata-rata berkisar antara 165,08248,27 ppm. Perlakuan penambahan starter yang menghasilkan kandungan lovastatin terendah yaitu pada bekasam dengan starter $10^{5} \mathrm{CFU} / \mathrm{mL}$, dan berturut-turut kandungan lovastatin tertinggi yaitu pada bekasam dengan penambahan starter $10^{7}$, bekasam tanpa penambahan starter dan bekasam dengan starter $10^{9} \mathrm{CFU} / \mathrm{mL}$. Nilai rata-rata kandungan lovastatin bekasam ikan seluang dapat dilihat pada Tabel 1.

Berdasarkan penelitian Rinto et al. $\left(2015^{\mathrm{a}}\right)$, rata-rata kandungan lovastatin bekasam ikan seluang dan ikan gabus yaitu 101,65 ppm dan 98,50 ppm. Zubaidah dan Oktanesia (2016), melaporkan bahwa kandungan lovastatin pada angkak yang difermentasi selama 8 hari yaitu 105,360 ppm sedangkan pada angkak bekatul dengan adanya penambahan kultur Saccharomyces cerevisiae $10^{5} \mathrm{CFU} / \mathrm{mL}$ dapat meningkatkan kandungan lovastatin yaitu 150,120 ppm.

Kandungan lovastatin bekasam ikan seluang secara umum mengalami fluktuasi yang menurun pada perlakuan penambahan starter $10^{5}$ dan $10^{9} \mathrm{CFU} / \mathrm{mL}$ dan mengalami peningkatan kandungan lovastatin pada perlakuan penambahan starter $10^{7} \mathrm{CFU} / \mathrm{mL}$. Hasil analisis sidik ragam menunjukkan bahwa perlakuan penambahan starter, menghasilkan nilai kandungan lovastatin bekasam yang berbeda nyata pada taraf 5\%. Berdasarkan hasil uji lanjut beda nyata terkecil (BNT) yang dilakukan, menunjukan bahwa kandungan lovastatin bekasam ikan seluang pada perlakuan tanpa penambahan starter berbeda nyata dengan semua perlakuan penambahan starter $10^{5}$, 107 dan $10^{9} \mathrm{CFU} / \mathrm{mL}$.

Kandungan statin pada perlakuan tanpa penambahan starter lebih tinggi dibandingkan pada penambahan starter $10^{5} \mathrm{CFU} / \mathrm{mL}$. Hal tersebut disebabkan karena proses fermentasi bekasam yang berlangsung secara spontan menyebabkan mikroorganisme yang berperan tidak hanya BAL sehingga diduga ada mikroorganisme yang dapat menghasilkan metabolit sekunder lovastatin misalnya kapang dan khamir. Peneliti sebelumnya melaporkan bahwa terdapat kandungan lovastatin pada Aspergillus terreus (Nauli dan Udin 2006), pada Monascus sp. (Singgih et al. 2013) dan Monascus purpureus (Tedjautama dan Zubaedah 2014). Lovastatin merupakan produk metabolit sekunder yang diproduksi ketika mikroorganisme tidak tumbuh dengan baik. Fungsi lovastatin bagi mikroorganisme salah satunya adalah sebagai agen antagonisme terhadap mikroorganisme lainnya (Rinto et al. 2015 ). Berdasarkan hasil penelitian Astuti et al. (2009), diketahui bahwa mengkonsumsi produk fermentasi yang mengandung bakteri asam laktat dapat menurunkan kadar kolesterol baik pada hewan maupun manusia.

\section{KESIMPULAN}

Perbedaan konsentrasi penambahan starter L. acidophilus dalam pembuatan bekasam ikan seluang berpengaruh nyata terhadap kadar protein, kadar $\mathrm{N}$-amino, dan kandungan lovastatin bekasam. Perlakuan terbaik yang menghasilkan bekasam dengan kandungan lovastatin tertinggi (248,27 ppm) terdapat pada perlakuan dengan penambahan starter L. acidophillus sebanyak $10^{7} \mathrm{CFU} / \mathrm{mL}$.

\section{UCAPAN TERIMAKASIH}

Ucapan terimakasih disampaikan kepada Universitas Sriwijaya yang telah mendanai penelitian ini melalui hibah SATEKS UNSRI 2016 melalui Kontrak No. 591/UN9.3.1/ LT/2016 Tanggal 22 April 2016. 


\section{DAFTAR PUSTAKA}

[AOAC] Association of Official Analytical Chemist. 1995. Official methods of analysis of the association of official analitical chemist. Virginia USA: Association of Official Analytical Chemist Inc. Arlington.

Astuti, Bachruddin Z, Supadmo, Harmayani E. 2009. Pengaruh pemberian bakteri asam laktat Streptococcus thermophilus terhadap kadar kolesterol darah ayam broiler strain lohman. Prosiding Seminar Nasional Penelitian, Pendidikan dan Penerapan MIPA. Universitas Negeri Yogyakarta.

Candra JI, Zahiruddin W, Desniar. 2007. Isolasi dan karakterisasi bakteri asam laktat dani produk bekasam ikan bandeng. Buletin Teknologi Hasil Perikanan. 10(2): 14-24.

Desniar, Rusmana I, Suwanto A, Mubarik NR. 2011. Penapisan bakteriosin dari bakteri asam laktat asal bekasam. Jurnal Pengolahan Hasil Perikanan Indonesia. 14(2): 124-133.

Desniar, Setyaningsih I, Sumardi RS. 2012a. Perubahan parameter kimia dan mikrobiologi serta isolasi bakteri penghasil asam selama fermentasi bekasam ikan mas (Cyprinus Carpio). Jurnal Pengolahan Hasil Perikanan Indonesia. 15(3): 232-239.

Desniar, Rusmana I, Suwanto A, Mubarik NR. 2012b. Senyawa antimikroba yang dihasilkan oleh bakteri asam laktat asal bekasam. Jurnal Akuatika. 3(2): 135-145.

Desniar, Setyaningsih I, Permana YI. 2016. Penapisan dan produksi antibakteri Lactobacillus plantarum yang diisolasi dari bekasam ikan nila Atin. Jurnal Pengolahan Hasil Perikanan Indonesia. 19(2): 132-139.

Herawati DA, Wibawa AA. 2011. Pengaruh konsentrasi susu skim dan waktu fermentasi terhadap hasil pembuatan soyghurt. Jurnal Ilmiah Teknik Lingkungan. 1(2): 452-329.

Hidayati L, Chisbiyah LA, Kiranawati TM. 2012. Evaluasi mutu organoleptik bekasam ikan wader. Jurnal Teknologi Industri Boga dan Busana. 3(1): 44-51.
Hidayat IR, Kusrahayu, Mulyani S. 2013. Total bakteri asam laktat, nilai $\mathrm{pH}$ dan sifat organoleptik drink yoghurt dari susu sapi yang diperkaya dengan ekstrak buah mangga. Animal Agriculture Journal. 2(1): 160-167.

Kalista A, Supriadi A, Rachmawati SH. 2012. Bekasam ikan lele dumbo (Clarias gariepinus) dengan penggunaan sumber karbohidrat yang berbeda. Jurnal Teknologi Hasil Perikanan. 1(1): 102-110.

Kasim E, Astuti S, Nurhidayat N. 2005. Karakterisasi pigmen dan kadar lovastatin beberapa isolat Monascus purpureus. Journal of Biological Diversity. 6(4): 245247.

Marini SM, Desniar, Santoso J. 2016. Karakteristik minuman jelly probiotik dengan penambahan Lactobacillus plantarum (SK5) asal bekasam selama penyimpanan. Jurnal Pengolahan Hasil Perikanan Indonesia. 19(3): 288-296.

Nauli T, Udin LZ. 2006. Model fermentasi lovastatin. Jurnal Akta Kimia Indonesia. 1(2): 99-104.

Rinto, Rahayu ES, Indrati R. 2006. Aplikasi Pediococcus acidilactici F-11 dalam menghambat pembentukan histamin selama fermentasi peda. Seminar Nasional dan Diseminasi. Teknologi Pengembangan Hasil Perikanan. Universitas Lampung.

Rinto, Dewanti R, Yasni S, Suhartono MT. 2015a. Potency of Bekasam "Indonesian Traditional Fermented Fish Product" As a Hmg-CoA Reductase Inhibitor. Global Advence Research Journal of Agricultural Science. 4(8): 467-473.

Rinto, Dewanti R, Yasni S, Suhartono MT. 2015b. Isolasi dan identifikasi bakteri asam laktat penghasil inhibitor enzim HMG-KoA reduktase dari bekasam sebagai agen pereduksi kolesterol Jurnal Agritech. 35(3): 309-314.

Rinto, Suhartono, MT. 2016. A Review on 3-hidroxy-3-methylglutaryl-coenzym A reductase and inhibitor: the Medies Potential of The Enzyme Inhibitor. Research Journal Pharmaceutical Biological Chemical Science. 7(2): 15691578. 
Rinto, Nopianti R, Herpandi, Oktaviani S. 2017. Fractionation of anticholesterol bioactive compounds from bekasam. Pertanika Journal of Tropical Agricultural Science. 40(3): 417-424.

Singgih M, Damayanti S, Saraswaty V, Ratnaningrum D, Priatni S. 2013. Pengaruh komposisi etanol pada ekstraksi senyawa antikolesterol dari produk fermentasi Monascus sp. Jurnal Sekolah Farmasi ITB dan Pusat Penelitian Kimia LIPI. 2013: 19-25.

Soetrisno USS, Apriyantono RRS. 2005. Mutu gizi dan keamanan bekasam produk fermentasi ikan teri secara spontan dan penambahan kultur murni. Jurnal Penelitian Gizi dan Makanan. 28(1): 3842.

Tedjautama E, Zubaidah E. 2014. Peningkatan produksi pigmen merah angkak tinggi lovastatin menggunakan ko-kultur Monascus purpureus dan Saccharomyces cerevisiae. Jurnal Pangan dan Agroindustri. 2(4): 78-88.

Usmam MF, Utami R, Widowati E. 2012. Kajian karakteristik minuman sinbiotik pisang kepok (Musa paradisiaca forma typical) dengan menggunakan starter Lactobacillus acidophillus IFO13951 dan Bifidobacterium longum ATCC 15707. Jurnal Teknosains Pagan. 1(1): 2-11.

Veljovic K, Terzic-Vedojevic A, Vukasinovic M, Strahinic I, Begovic J, Lozo J, Ostojic M, Topisirovic L. 2007. Preliminary characterization of lactic acid bacteria isolated from Zlatar cheese. Journal of Applied Microbiology. 103: 2142-2152.

Widowati TW, Taufik M, Wijaya A. 2011. Pengaruh pra fermentasi garam terhadap karakteristik kimiawi dan mikrobiologis bekasam ikan patin. Prosiding Seminar Nasional dan Rapat Tahunan Dekan, Bidang Ilmu-Ilmu Pertanian BKS-PTN Wilayah Barat. Universitas Sriwijaya.

Wikandari PR, Suparmo, Marsono Y, Rahayu ES. 2012. Karakterisasi Bakteri Asam Laktat Proteolitik pada Bekasam. Jurnal Natur Indonesia. 14(2): 120-125.

Wikandari PR, Yuanita L. 2014. Potensi bekasam yang difermentasi dengan Lactobacillus plantarum B1765 dalam menurunkan tekanan darah tikus hipertensi. Prosiding Seminar Nasional Kimia, Program Studi Kimia, Fakultas MIPA. Universitas Negeri Surabaya.

Yanti IW, Dali FA. 2013. Karakterisasi bakteri asam laktat yang diisolasi selama fermentasi bekasang. Jurnal Pengolahan Hasil Perikanan Indonesia. 16(2): 133141.

Zubaidah E, Oktanesia R. 2016. Potensi angkak ko-kultur Saccharomyces cerevisiae tinggi lovastatin sebagai agen terapi tikus hiperkolesterolemia. Jurnal Pangan dan Agroindustri. 4(1): 211-220. 